Article

\title{
New 1-Aryl-3-Substituted Propanol Derivatives as Antimalarial Agents
}

Silvia Pérez-Silanes ${ }^{1, *}$, Luis Berrade ${ }^{1}$, Rory N. García-Sánchez ${ }^{2}$, Adela Mendoza ${ }^{1}$, Silvia Galiano ${ }^{1}$, Berta Martín Pérez-Solórzano ${ }^{2}$, Juan J. Nogal-Ruiz ${ }^{2}$, Antonio R. Martínez-Fernández ${ }^{2}$, Ignacio Aldana ${ }^{1}$ and Antonio Monge ${ }^{1}$

1 Unidad en Investigación y Desarrollo de Medicamentos, Centro de Investigación en Farmacobiología Aplicada (CIFA), University of Navarra, c/Irunlarrea s/n, 31080 Pamplona, Spain; E-Mail: luisberrade@msn.com (L.B.)

2 Departamento de Parasitología, Facultad de Farmacia, Complutense University of Madrid, Spain

* Author to whom correspondence should be addressed; E-Mail: sperez@unav.es.

Received: 11 August 2009; in revised form: 21 September 2009 / Accepted: 14 October 2009 / Published: 14 October 2009

\begin{abstract}
This paper describes the synthesis and in vitro antimalarial activity against a $P$. falciparum 3D7 strain of some new 1-aryl-3-substituted propanol derivatives. Twelve of the tested compounds showed an $\mathrm{IC}_{50}$ lower than $1 \mu \mathrm{M}$. These compounds were also tested for cytotoxicity in murine $\mathbf{J} 774$ macrophages. The most active compounds were evaluated for in vivo activity against $P$. berghei in a 4-day suppressive test. Compound 12 inhibited more than $50 \%$ of parasite growth at a dose of $50 \mathrm{mg} / \mathrm{kg} /$ day. In addition, an FBIT test was performed to measure the ability to inhibit ferriprotoporphyrin biocrystallization. This data indicates that 1-aryl-3-substituted propanol derivatives hold promise as a new therapeutic option for the treatment of malaria.
\end{abstract}

Keywords: antimalarial agents; benzo[b]thiophene; 1-aryl-3-substituted propanol derivatives; P. Falciparum; ferriprotoporphyrin

\section{Introduction}

Malaria is a major health disease with hundreds of millions of people being infected. Approximately $50 \%$ of the world's population, mostly those living in the world's poorest countries, 
are at risk of malaria [1]. Every year, more than 500 million people become severely ill with malaria. Most cases and deaths occur in tropical and subtropical countries. Early diagnosis and prompt treatment are the basic elements needed for the control of this condition.

Chloroquine was the most effective and widely used drug in malaria therapy because of its rapid onset of action, good tolerability and low cost. However, the increasing resistance of the malaria parasite Plasmodium falciparum to currently available drugs, and especially to chloroquine, demands a continuous effort to develop new effective therapeutic options [2].

The arylamine alcohols (Figure 1) are antimalarial drugs structurally derived from quinine. Mefloquine is considered a standard therapeutic agent for chloroquine-resistant malaria; however, its use is limited by high costs and the appearance of neuropsychiatric side effects [3]. The administration of halofantrine is highly effective, but has been severely restricted due to its potential to induce fatal adverse cardiac effects [4]. Lumefantrine, which is an analogue of halofantrine with no cardiac effects, is available coformulated with arthemether in an oral preparation [5].

Strains of $P$. falciparum that are resistant to chloroquine and many other antimalarial drugs have since emerged and this has created a near desperate situation, where the need for new, inexpensive antimalarial agents has become vital. Identification of new molecular scaffolds structurally unrelated to existing antimalarial agents represents a valuable strategy to bypass resistance phenomena.

Figure 1. Antimalarial drugs: Arylaminealcohol derivatives.



More recently aminopropanol derivatives have been described as antimalarial agents [6-8], so we focused our attention on a series of 1-aryl-3-[4-arylpiperazin-1-yl]-1-propane derivatives synthesized by our group and recently published as antidepressants [9-12] (Figure 2). Our efforts have been 
focused on identifying new antimalarial drug candidates. As a result, we thought that the structural similarity of our compounds with the active arylamine alcohols in Figure 1 could also be interesting. Therefore, after several months of coordinated work between the synthesis and experimental chemotherapy, we report the synthesis and the antimalarial activity of 1-aryl-3-substituted propanol derivatives. We carried out both in vitro and in vivo assays in order to determine whether our compounds have potential for being considered as future antimalarial drugs. In addition, we performed an easy in vitro test in order to measure the ability of the compounds to inhibit the biomineralization process from ferriprotoporphyrin IX to hemozoin, as a possible mechanism of action.

\section{Results and Discussion}

The synthesis of some of the tested compounds has been published previously [9-12] (see reference publications in Tables 1-3. Methods for the synthesis of compounds 6-10, 16, 28-35, 38, 40, 41, 44 and 45 are presented in Schemes 1-3, while derivatives 1-5, 11-15, 17-27, 36, 37, 39, 42 and 43 were previously reported [9-11].

The benzo[b]thiophene derivatives 6-10 were prepared using the 1-(3-benzo[b]thio phenyl)-3chloropropan-1-one precursor IV previously synthesized by a Friedel-Craft acylation of benzo[b]thiophene as described in [12]. Ketones were obtained by a $\mathrm{S}_{\mathrm{N}} 2$ nucleophilic attack of the corresponding arylamine III to IV (Scheme 1).

The ketone intermediates VI were prepared by condensation of the corresponding commercially available acetophenones $\mathbf{V}$ with the different aryl amines III via Mannich reactions[12] (Scheme 2).

Scheme 1. Synthesis of benzo[b]thiophenyl propanol derivatives 6-10, 16 and 28-35.

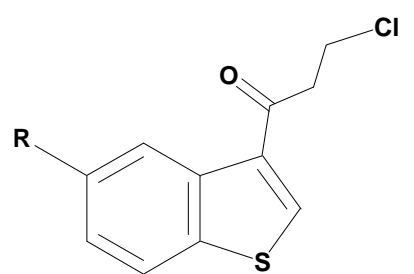

(IV)

(III)

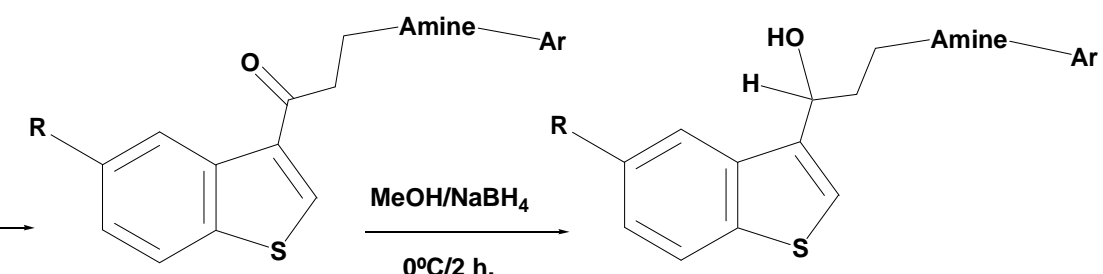

$(6-10)$

(16), (28 - 35)

Scheme 2. Synthesis of 1-aryl-3-substituted propanol derivatives 38, 40, 41, 44 and 45.

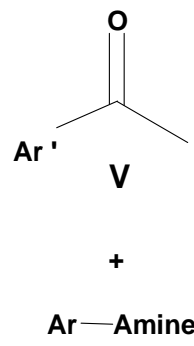

(III)

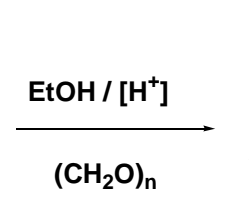

Ar

$(\mathrm{VI})$

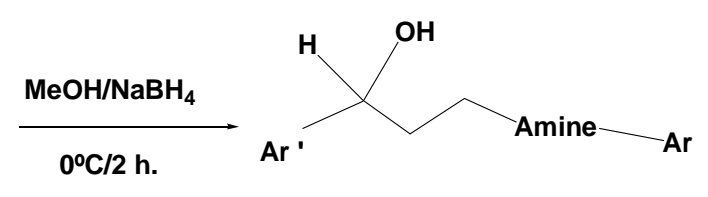

(38), (40), (41), (44), (45) 
The 4-chloro-, 2-methoxy- and 3-methoxyphenyl piperazines were commercially available. The rest of the aryl amines were synthesized using the corresponding BOC-arylamines and $p$-nitrophenyl, $p$ nitro-o-trifluoromethylphenyl and 2-quinoxalinyl aryl fluorides by an SNAr reaction [13] and subsequent removal of the BOC-group with $\mathrm{HCl}$ and acetic acid (Scheme 3).

Scheme 3. Synthesis of the non-commercially available arylamines.

$$
\text { BOC-Amine }
$$

(I)

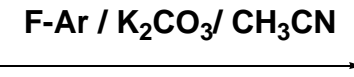

reflux $48 \mathrm{~h}$.
Ar-Amine-BOC

(II)

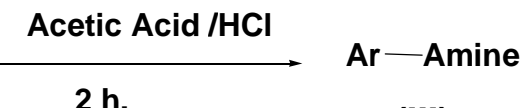

(III)

Finally, all the hydroxyl derivatives 11-46 were obtained by reduction of the corresponding carbonyl group with $\mathrm{NaBH}_{4}$ in methanol. All of the compounds were chemically characterized by thin layer chromatography (TLC), melting point (m.p.), infrared (IR) and nuclear magnetic resonance $\left({ }^{1} \mathrm{H}-\right.$ NMR) spectra, as well as by elemental microanalysis.

Forty-six compounds were evaluated for in vitro antimalarial activity against $P$. falciparum, and twelve of them showed good activity, with $\mathrm{IC}_{50}$ values lower than $1 \mu \mathrm{M}$. We paid special attention to compounds 12, 15, 22, 23 and 31 since they were the most active, only two to fourfold less active than chloroquine. On the other hand, twenty-nine compounds showed moderate or low activity with $\mathrm{IC}_{50}$ values between 1 and $14.63 \mu \mathrm{M}$. All other compounds were considered to be inactive because they either showed no activity or their activity was quite insignificant (see Tables 1 and 2). Chloroquine, the positive control, showed an $\mathrm{IC}_{50}$ of $0.08 \mu \mathrm{M}$, which coincides with the value reported by other authors.

Table 1. In vitro antimalarial activity of Benzo[b]thiophenyl derivatives versus Chloroquine Sensitive $\cdot 3$ D7 Strain of Plasmodium falciparum.

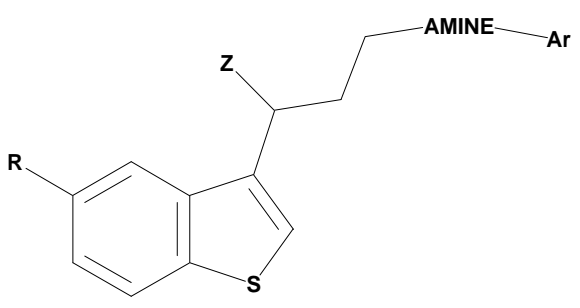

\begin{tabular}{cccccc}
\hline Compd. & $\mathbf{R}$ & $\mathbf{Z}$ & Amine & Ar & $\begin{array}{c}\text { P. falciparum 3D7 } \\
\text { IC }_{50} \mu \mathbf{M}\end{array}$ \\
\hline $\mathbf{1}^{\mathbf{a}}$ & $\mathrm{F}$ & $\mathrm{C}=\mathrm{O}$ & 1-naphthyl & $\mathrm{IN}$ \\
$\mathbf{2}^{\mathbf{c}}$ & $\mathrm{F}$ & $\mathrm{C}=\mathrm{O}$ & 2-methoxyphenyl & $\mathrm{IN}$ \\
$\mathbf{3}^{\mathbf{b}}$ & $\mathrm{H}$ & $\mathrm{C}=\mathrm{O}$ & 2-methoxyphenyl & $\mathrm{IN}$ \\
$\mathbf{4}^{\mathbf{a}}$ & $\mathrm{F}$ & $\mathrm{C}=\mathrm{O}$ & 8-quinolyl & $\mathrm{IN}$ \\
$\mathbf{5}^{\mathbf{a}}$ & $\mathrm{H}$ & $\mathrm{C}=\mathrm{O}$ & 8-quinaldinyl & $\mathrm{IN}$ \\
$\mathbf{6}$ & $\mathrm{H}$ & $\mathrm{C}=\mathrm{O}$ & 4-nitro-2-trifluromethyl phenyl & $\mathrm{IN}$ \\
$\mathbf{7}$ & $\mathrm{H}$ & $\mathrm{C}=\mathrm{O}$ & 4-nitrophenyl & $\mathrm{IN}$ \\
$\mathbf{8}$ & $\mathrm{H}$ & $\mathrm{C}=\mathrm{O}$ & - \\
$\mathbf{9}$ & $\mathrm{H}$ & $\mathrm{C}=\mathrm{O}$ & & 4-nitrophenyl & $\mathrm{IN}$ \\
\hline
\end{tabular}


Table 1. Cont.

\begin{tabular}{|c|c|c|c|c|c|}
\hline 10 & $\mathrm{H}$ & $\mathrm{C}=\mathrm{O}$ & $\sqrt{\widetilde{N}^{N-}}$ & 2-quinoxaline & IN \\
\hline $11^{\mathrm{a}}$ & $\mathrm{H}$ & $\mathrm{OH}$ & $\sim_{-N}^{N-}$ & 1-naphthyl & 6.13 \\
\hline $12^{\mathrm{a}}$ & $\mathrm{F}$ & $\mathrm{OH}$ & $-\widetilde{N}^{N-}$ & 1-naphthyl & 0.16 \\
\hline $13^{b}$ & $\mathrm{H}$ & $\mathrm{OH}$ & $-\sqrt{N}^{N-}$ & 2-methoxyphenyl & 1.07 \\
\hline $14^{\mathrm{b}}$ & $\mathrm{H}$ & $\mathrm{OH}$ & $-n=$ & 2-hydroxyphenyl & 13.73 \\
\hline $15^{c}$ & $\mathrm{~F}$ & $\mathrm{OH}$ & $-\sqrt{n}^{N-}$ & 2-methoxyphenyl & 0.33 \\
\hline 16 & $\mathrm{~F}$ & $\mathrm{OH}$ & $-\widetilde{N}^{N-}$ & 3-methoxyphenyl & 1.67 \\
\hline $17^{\mathrm{a}}$ & $\mathrm{H}$ & $\mathrm{OH}$ & $-\sim^{N-}$ & 4-indolyl & 6.99 \\
\hline $18^{\mathrm{a}}$ & $\mathrm{F}$ & $\mathrm{OH}$ & & 4-indolyl & 3.81 \\
\hline $19^{b}$ & $\mathrm{H}$ & $\mathrm{OH}$ & $-\sqrt{-1}$ & 4-chlorophenyl & 5.65 \\
\hline $20^{\mathrm{a}}$ & $\mathrm{H}$ & $\mathrm{OH}$ & $-\sqrt{-1}$ & 8-quinolyl & 2.15 \\
\hline $21^{\mathrm{a}}$ & $\mathrm{F}$ & $\mathrm{OH}$ & $-\sqrt{-1}$ & 8-quinolyl & 0.79 \\
\hline $22^{\mathrm{a}}$ & $\mathrm{H}$ & $\mathrm{OH}$ & $-\sqrt{-1}$ & 8-quinaldinyl & 0,66 \\
\hline $23^{\mathrm{a}}$ & $\mathrm{F}$ & $\mathrm{OH}$ & $-{ }^{-}$ & 8-quinaldinyl & 0.38 \\
\hline $24^{\mathrm{a}}$ & $\mathrm{H}$ & $\mathrm{OH}$ & $-{ }^{-}-$ & 5-quinolyl & 1.30 \\
\hline $25^{\mathrm{a}}$ & $\mathrm{H}$ & $\mathrm{OH}$ & $-n=$ & 2-quinolyl & 2.22 \\
\hline $26^{\mathrm{a}}$ & $\mathrm{H}$ & $\mathrm{OH}$ & $-\sqrt{-1}$ & 2,3-dihydro-1,4-benzodioxin-5-yl & 3.56 \\
\hline $27^{\mathrm{a}}$ & $\mathrm{F}$ & $\mathrm{OH}$ & $-{ }^{-}$ & 2,3-dihydro-1,4-benzodioxin-5-yl & 0.90 \\
\hline 28 & $\mathrm{H}$ & $\mathrm{OH}$ & & 4-nitro-2-trifluromethyl phenyl & 0.68 \\
\hline 29 & $\mathrm{H}$ & $\mathrm{OH}$ & & 4-nitro-2-trifluromethyl phenyl & 2.99 \\
\hline 30 & $\mathrm{H}$ & $\mathrm{OH}$ & & 4-nitro-2-trifluromethyl phenyl & 0.97 \\
\hline 31 & $\mathrm{H}$ & $\mathrm{OH}$ & . & 4-nitro-2-trifluromethyl phenyl & 0.19 \\
\hline 32 & $\mathrm{~F}$ & $\mathrm{OH}$ & - & 4-nitrophenyl & IN \\
\hline 33 & $\mathrm{H}$ & $\mathrm{OH}$ & & 4-nitrophenyl & 1.00 \\
\hline 34 & $\mathrm{H}$ & $\mathrm{OH}$ & & 4-nitrophenyl & 3.43 \\
\hline 35 & $\mathrm{H}$ & $\mathrm{OH}$ & $-\sqrt{-1}$ & 2-quinoxalinyl & 0.62 \\
\hline Chloroq. & & & & & 0.08 \\
\hline
\end{tabular}

${ }^{\mathrm{a}}$ Drugs from [11]; ${ }^{\mathrm{b}}$ Drugs from [9]; ${ }^{\mathrm{c}}$ Drugs from [10]. $\mathrm{IC}_{50}$ is the $50 \%$ inhibitory concentration of the in vitro parasite growth. Each value is the mean of two experiments in triplicate. All the compounds with $\mathrm{IC}_{50}$ value higher than $20 \mu \mathrm{M}$ was considered inactive (IN).

From the point of view of the SAR and in order to assess the importance of the $\mathrm{OH}$ group present in the arylamine moiety, the in vitro antimalarial activity of some ketone intermediates (compounds 1-10) against $P$. falciparum was evaluated. It is important to point out that none of them were active. This fact suggests that the $\mathrm{OH}$ group present in the arylamine moiety is essential for the activity. In addition, an increase in the activity was observed in the benzothiophene derivatives, when substituted in position 5 with an electron withdrawing group $(\mathrm{R}=\mathrm{F}$; compounds $12,15,18,21,23,27)$ in comparison with the corresponding unsubstituted derivatives $(\mathrm{R}=\mathrm{H}$; compounds 11, 13, 17, 20, 22, 26). Regarding the different amines employed, the activity data suggest that the most interesting compounds are those containing the 4-aminopiperidine moiety (see compounds 28-31 and 32-34). Finally, it is evident that the presence of a benzocondensed group in Ar' (benzothiophenyl or naftyl) contributes to a notable improvement in the activity compared to other aromatic substituents. 
Before testing the in vivo antimalarial activity, we evaluated the cytoxicity of every active compound on a murine macrophages $\mathrm{J} 774$ cell line. Although the majority of them were toxic at 100 $\mu \mathrm{g} / \mathrm{mL}$, only compound 31 showed toxicity at $10 \mu \mathrm{g} / \mathrm{mL}$. From our point of view, if a compound shows a toxicity percentage higher than $30 \%$ at this concentration, it will be toxic in vivo. However, we decided to include it in an in vivo test with mice (Table 3). Only compound 12 inhibited more than $50 \%$ of parasite growth and the appearance of the mice was good at the end of the experiment. The mice in groups treated with compounds $\mathbf{2 3}$ and $\mathbf{1 5}$ looked unhealthy and showed clear evidence of weight loss. Unfortunately, the cytotoxicity of compound 31 was confirmed in the in vivo test.

Ferriporotoporphyrin IX (FPIX) biocrystallization is a Plasmodium-specific process in which the toxic FPIX derived from the digestion of ingested haemoglobin is converted into an insoluble nontoxic crystalline species called haemozoin. This is the mechanism through which chloroquine exerts its antimalarial effect. Due to the structural similarity of our compounds with other antimalarial arylamine alcohol derivatives, we felt that it could be important to examine this. The results showed that no compound was active in the FBIT test. This fact supports the hypothesis that 1-aryl-3-substituted propanol derivatives, such as quinine, have a weaker binding coefficient to FP [14]. This was demonstrated by Deharo [15], who reported an $\mathrm{IC}_{50}=324 \mu \mathrm{M}$ for quinine in the FBIT test. This fact is of great importance because the parasite has developed resistance to the majority of the antimalarials of the 4-aminoquinoline group, all of which inhibit the formation of haemozoin.

Table 2. In vitro antimalarial activity of 1-aryl-3-substituted propanol derivatives versus Chloroquine Sensitive $\cdot 3$ D7 Strain of Plasmodium falciparum.

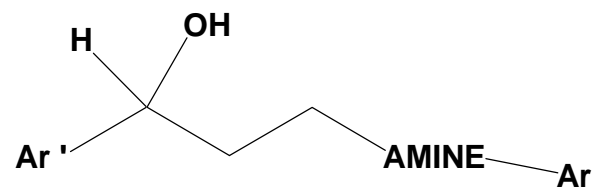

\begin{tabular}{|c|c|c|c|c|}
\hline Compd. & Ar' & Amine & Ar & $\begin{array}{c}\text { P. falciparum 3D7 } \\
\text { IC }_{50} \mu \mathrm{M}\end{array}$ \\
\hline $36^{b}$ & 3-thiophenyl & $\sqrt{-N-}^{N-}$ & 4-chlorophenyl & IN \\
\hline $37^{\mathrm{b}}$ & phenyl & $\widetilde{N}^{N-}$ & 4-chlorophenyl & 13.04 \\
\hline 38 & biphenyl & $-\sqrt{-N-}^{N-}$ & 4-chlorophenyl & IN \\
\hline $39^{b}$ & phenyl & $-\overbrace{}^{N-}$ & 2-methoxyphenyl & IN \\
\hline 40 & biphenyl & $-\overbrace{}^{N-}$ & 2-methoxyphenyl & 14.63 \\
\hline 41 & 3-indolyl & $-\sqrt{-N-}^{N-}$ & 2-methoxyphenyl & IN \\
\hline $42^{b}$ & 2-naphthyl & $-\overbrace{}^{N-}$ & 2-methoxyphenyl & 0.83 \\
\hline $43^{\mathrm{a}}$ & $2,4-$ & $-\overbrace{}^{N-}$ & 2-methoxyphenyl & 16.91 \\
\hline 44 & 6-methylnapht-2- & $-\sqrt{-N-}^{N-}$ & 2-methoxyphenyl & 9.64 \\
\hline 45 & 2-naphthyl & ${ }_{n}^{-}-C_{n-}$ & 4-nitro-2-trifluromethyl phenyl & 9.10 \\
\hline $46^{\mathrm{a}}$ & $2,4-$ & $-\approx^{N-}$ & 2-hydroxyphenyl & 18.16 \\
\hline Chloroq. & & & & 0.08 \\
\hline
\end{tabular}

${ }^{a}$ Drugs from [11]; ${ }^{\mathrm{b}}$ Drugs from [9]. $\mathrm{IC}_{50}$ is the $50 \%$ inhibitory concentration of the in vitro parasite growth. Each value is the mean of two experiments in triplicate. All the compounds with $\mathrm{IC}_{50}$ value higher than 20 $\mu \mathrm{M}$ was considered inactive (IN). 
Table 3. In vivo antimalarial activity of selected 1-aryl-3-arylamino propanol derivatives against Plasmodium berghei ANKA strain.

\begin{tabular}{|c|c|c|c|c|}
\hline Compd. & Ar' & Amine & Ar & $\begin{array}{c}\text { GIP of } \\
P . \text { bergei } \\
\text { at } 50 \mathrm{mg} / \mathrm{kg} / \mathrm{day}\end{array}$ \\
\hline 12 & 5-F-Benzo[b]thiophenyl & $\overbrace{N} \approx$ & 1-naphthyl & 65,79 \\
\hline 23 & 5-F-Benzo[b]thiophenyl & $-\overbrace{}^{N-}$ & 8-quinaldinyl & 37,69 \\
\hline 15 & 5-F-Benzo[b]thiophenyl & $-\sqrt{n}^{N-}$ & 2-methoxyphenyl & 24,73 \\
\hline 31 & Benzo[b]thiophenyl & $\rightarrow{ }^{-1}-1$ & 4- $\mathrm{NO}_{2}-2-\mathrm{CF}_{3}-$ phenyl & Toxic \\
\hline Chloroq. & & & & $\begin{array}{c}100 \% \text { at } 10 \\
\mathrm{mg} / \mathrm{kg}\end{array}$ \\
\hline
\end{tabular}

GIP $=$ Growth inhibition percentage of the rodent malaria parasite after a four-day treatment. $10 \mathrm{mg} / \mathrm{kg} / \mathrm{day}$ of chloroquine, positive control, inhibited $100 \%$ the growth parasite. ${ }^{a}$ Toxic $=$ death of more than half of the animals in the tested group.

\section{Experimental}

\subsection{Biological evaluation}

\subsubsection{In vitro antimalarial activity screening against Plasmodium falciparum}

The SYBR ${ }^{\odot}$ GreenI-based micromethod [16] was followed for testing the antimalarial activity of the compounds. Erythrocytic stages of $P$. falciparum 3D7 strain, chloroquine sensitive, were maintained in RPMI 1640 culture medium supplemented with $0.5 \%$ Albumax II at $37{ }^{\circ} \mathrm{C}$ in an atmosphere with $5 \%$ $\mathrm{CO}_{2}$. An erythrocyte suspension, with initial $1 \%$ parasitemia and $4 \%$ hematocrit, was prepared using the aforementioned culture and then distributed into a 96-well plate, $50 \mu \mathrm{L}$ per well. Next, stock solutions of each compound were prepared in DMSO and diluted in RPMI medium in order to obtain concentrations from 10 to $0.01 \mu \mathrm{g} / \mathrm{mL}$. The final DMSO concentration was never higher than $0.1 \%$. $50 \mu \mathrm{L}$ of each prepared concentration were added per well. DMSO and chloroquine were included as a negative and positive control, respectively. All compounds and controls were placed in triplicate. The plate was incubated under the same conditions. After $48 \mathrm{~h}$, the plate was removed from the incubator and frozen for at least $1 \mathrm{~h}$ at $-70{ }^{\circ} \mathrm{C}$ and then thawed. Finally, $100 \mu \mathrm{L}$ of SYBR ${ }^{\circ} \mathrm{GreenI}$ in lysis buffer $(0.2 \mu \mathrm{L} / \mathrm{mL})$ was added per well and shaken for 5 minutes or until no precipitated erythrocytes were observed. The plate was left to stand in the dark for $1 \mathrm{~h}$ at room temperature. Fluorescence intensity (FI) for each well was measured. The background of the nonparasitized erythrocytes was subtracted from each well tested. Percentage inhibition of the parasite growth for each concentration was calculated by using the following formula:

$$
\% \text { inhibition }=100 \times[(\text { F.I.control }- \text { F.I.comp }) /(\text { F.I.control })]
$$

$\mathrm{IC}_{50}$ values were estimated by plotting drug concentration versus percentage inhibition. 


\subsubsection{Nonspecific cytotoxicity tests [17]}

Murine J774 macrophages were maintained in RPMI 1640 medium supplemented with 10\% FBS at $37{ }^{\circ} \mathrm{C}$ in a $5 \% \mathrm{CO}_{2}$ atmosphere. First, in a flat bottom 96-well microplate, $100 \mu \mathrm{L}$ of macrophage suspension in RPMI medium, containing $5 \times 10^{4}$ cells, were distributed per well. The cells were allowed to attach for $24 \mathrm{~h}$ at $37^{\circ} \mathrm{C}$. Next, the medium was replaced by different concentrations of the compounds in $200 \mu \mathrm{L}$ of medium, or DMSO at the same concentration as growth control, and the cells were exposed to the compounds solutions for another $24 \mathrm{~h}$. Each concentration was assayed three times. Afterwards, the medium was eliminated and $100 \mu \mathrm{L} /$ well of 3-(4,5-dimethythiazol-2-yl)-2,5diphenyltetrazolium bromide (MTT) solution, $0.4 \mathrm{mg} / \mathrm{mL}$ in PBS, was added and the plates were returned to incubator for $1 \mathrm{~h}$. The suspension was removed and the toxic effect of the compounds was assessed by the reduction of MTT to formazan crystals (as a cell viability indicator); said crystals were solubilized by adding $100 \mu \mathrm{L}$ of DMSO. Finally, the optical density (OD) was measured at $595 \mathrm{~nm}$ and the toxicity percentage was calculated as follows:

$$
\% \text { toxicity }=[(\text { O.D.control }- \text { O.D.comp }) /(\text { O.D.control })] \times 100
$$

\subsubsection{In vivo antimalarial activity}

The in vivo antimalarial activity of the compounds was measured by the classical 4-day suppressive test [18]. Briefly, on day 0, groups of five NMRI male mice, weighing $20 \pm 2 \mathrm{~g}$ each , were inoculated with $2 \times 10^{7}$ red blood cells RBCs infected by erythrocytic stages of rodent malaria parasite P. berghei ANKA strain. Two hours later, each group of mice was treated intraperitoneally with a dose of $50 \mathrm{mg} / \mathrm{kg}$ of the selected compound, previously prepared in DMSO. Treatment was continued from day 1 to day 3, always at similar times. On day 4, Giemsa-stained thin blood smears from the tail of the mice were prepared and microscopically examined with $1,000 \times$ magnification. The mean of the parasitemia of each group was calculated in a total of $1,000 \mathrm{RBCs}$, and the growth inhibition percentage of parasite was estimated in relation to the control group, which received only the solvent of the products.

$$
\% \text { inhibition }=[(\text { Par control }- \text { Par comp }) /(\text { Par control })] \times 100
$$

\subsubsection{Ferriprotoporphyrin IX biomineralization inhibition test (FBIT)}

The procedure for testing FP biomineralization was carried out according to the method described by Deharo [15]. A mixture containing $50 \mu \mathrm{L}$ of a $10 \mathrm{mg} / \mathrm{mL}$ drug solution or $50 \mu \mathrm{L}$ of solvent (for control), $50 \mu \mathrm{L}$ of $0.5 \mathrm{mg} / \mathrm{mL}$ of haemin chloride (Sigma $\mathrm{H}$ 5533) freshly dissolved in dimethylsulphoxide (DMSO) and $100 \mu \mathrm{L}$ of $0.5 \mathrm{M}$ sodium acetate buffer $\mathrm{pH} 4.4$ was incubated in a non-sterile flat bottom 96 -well plate at $37{ }^{\circ} \mathrm{C}$ for $18-24 \mathrm{hrs}$. After incubation, the plate was centrifuged at $1,600 \mathrm{~g}$ for $5 \mathrm{~min}$ and the supernatant was discarded. The remaining pellet was resuspended with $200 \mu \mathrm{L}$ of DMSO in order to remove unreacted FP. The plate was then centrifuged once again and the supernatant discarded. The pellet (precipitate of $\beta$-haematin), was dissolved in $150 \mu \mathrm{L}$ of $0.1 \mathrm{M} \mathrm{NaOH}$ 
and the absorbance quantified at $405 \mathrm{~nm}$ with a microplate reader. The data was expressed as the percentage of inhibition of FP biomineralization, calculated using the following equation:

$$
\% \text { inhibition }=100 \times[(\text { O.D.control }- \text { O.D.drug }) /(\text { O.D.control })]
$$

\subsection{Chemistry}

The ${ }^{1} \mathrm{H}-\mathrm{NMR}$ spectra were recorded on a Bruker 400 Ultrashield (400 MHz) (Bruker, Rheinstetten, Germany), using TMS as internal standard and chloroform $\left(\mathrm{CDCl}_{3}\right)$ or dimethyl sulfoxide- $d_{6}$ (DMSO$\left.d_{6}\right)$ as solvents; the chemical shifts are reported in ppm $(\delta)$, and coupling constant $(J)$ values are given in Hertz (Hz). Signal multiplicities are represented by: s (singlet), bs (broad singlet), d (doublet), t (triplet), q (quadruplet), dd (double doublet) and $\mathrm{m}$ (multiplet). The IR spectra were registered on a Thermo Nicolet FT-IR Nexus Euro (Thermo, Madison, WI, USA) using KBr pellets; the frequencies are expressed in $\mathrm{cm}^{-1}$. Elemental microanalyses were obtained on an Elemental Analyzer (LECO CHN-900, Leco, Tres Cantos Spain) from vacuum-dried samples. The analytical results for $\mathrm{C}, \mathrm{H}$, and $\mathrm{N}$ were within \pm 0.4 of the theoretical values. Alugram SIL G/UV254 (Layer: $0.2 \mathrm{~mm}$ ) (MachereyNagel GmbH \& Co. KG. Germany) was used for thin layer chromatography and silica gel 60 $(0.040-0.063 \mathrm{~mm})$ for column flash chromatography (Merck). Chemicals were purchased from E. Merck (Darmstadt, Germany), Scharlau (F.E.R.O.S.A., Barcelona, Spain), Panreac Química S.A. (Montcada i Reixac, Barcelona, Spain), Sigma-Aldrich Química, S.A., (Alcobendas, Madrid, Spain, ), Acros Organics (Janssen Pharmaceuticalaan, Geel, Belgium) and Lancaster (Bischheim-Strasbourg, France).

\subsubsection{General method for the synthesis of protected aryl amines II}

A mixture of the aryl fluoride (1 eq), the protected amine $\mathbf{I}(1.2 \mathrm{eq}), \mathrm{K}_{2} \mathrm{CO}_{3}(1.2 \mathrm{eq})$ and $\mathrm{CH}_{3} \mathrm{CN}$ $(50 \mathrm{~mL})$ was heated at reflux for 48 hours. The solvent was removed under reduced pressure, the residue was dissolved in $\mathrm{CH}_{2} \mathrm{Cl}_{2}(50 \mathrm{~mL})$ and washed with water $(3 \times 30 \mathrm{~mL})$. The organic phase was dried with anhydrous $\mathrm{Na}_{2} \mathrm{SO}_{4}$ and filtered. After evaporating to dryness under reduced pressure, the residue was precipitated and washed by adding diethyl ether or petroleum ether, affording the desired protected aryl amine II.

\subsubsection{General method for the preparation of deprotected amines III}

The protected amine II was dissolved in $40 \mathrm{~mL}$ of a solution of $\mathrm{HCl} / \mathrm{AcOH}$ (1:1) with stirring for 2 hours at room temperature. The solvent was removed under reduced pressure and the compound was dissolved in water. The aqueous solution was basified with $\mathrm{NaOH} 2 \mathrm{M}$ to basic $\mathrm{pH}$ and stirred for 1 hour. Then the product was extracted with $\mathrm{CH}_{2} \mathrm{Cl}_{2}$. The organic phase was dried with anhydrous $\mathrm{Na}_{2} \mathrm{SO}_{4}$ and filtered. After evaporating to dryness under reduced pressure the residue was precipitated and washed by adding diethyl ether or petroleum ether, affording the desired deprotected amine III.

\subsubsection{General method for the synthesis of ketones 6-10}

A mixture of 1-(benzo[b]thiophen-3-yl)-3-chloropropan-1-one IV (1 eq), the arylamine III (1.2 eq) and $\mathrm{K}_{2} \mathrm{CO}_{3}(1.2 \mathrm{eq})$ was stirred in THF $(50 \mathrm{~mL})$ for 72 hours at room temperature. The solvent was 
removed under reduced pressure and the residue was dissolved in $\mathrm{CH}_{2} \mathrm{Cl}_{2}(40 \mathrm{~mL})$ and washed with water $(3 \times 30 \mathrm{~mL})$. After evaporating to dryness under reduced pressure the residue was purified by column chromatography (SP: silica gel), eluting with $\mathrm{CH}_{2} \mathrm{Cl}_{2} /$ methanol 99:1 (v/v). In some cases the compound has been purified by preparative chromatography (SP: silica gel), eluting with $\mathrm{CH}_{2} \mathrm{Cl}_{2} /$ methanol 95:5 (v/v). In the cases in which the hydrochloride salt was prepared, the process consisted in adding an ethereal hydrogen chloride solution to a dichloromethane solution of the compound.

\subsubsection{General method for the synthesis of ketones VI}

A mixture of the appropriated substituted acetophenone $\mathbf{V}$ (1 eq), arylamine III or a commercially available one (1 eq) in absolute $\mathrm{EtOH}(40 \mathrm{~mL})$ and concentrated $\mathrm{HCl}(\mathrm{pH}=2-3)$ was heated at reflux. Paraformaldehyde ( 3 eq) was added in four equal portions over a period of $40 \mathrm{~min}$. The reaction mixture was refluxed for another $24 \mathrm{~h}$, cooled and poured onto crushed ice. The separated solid was filtered, dried and recrystallized from 1-propanol.

\subsubsection{General method for preparation of hydroxyl derivatives 16, 28-35, 38, 40, 41, 44 and 45}

Sodium borohydride ( $3 \mathrm{eq})$ was added little by little to a precooled suspension $\left(0{ }^{\circ} \mathrm{C}, 5 \mathrm{~min}\right)$ of the corresponding ketone $(1 \mathrm{eq})$ in methanol $(40 \mathrm{~mL})$ over a period of 30-60 minutes. The solvent was removed under reduced pressure and the residue dissolved in dichloromethane $(40 \mathrm{~mL})$ was washed with water $(3 \times 30 \mathrm{~mL})$. The organic phase was dried with anhydrous $\mathrm{Na}_{2} \mathrm{SO}_{4}$ and filtered. After evaporating the solvent to dryness under reduced pressure, the compound was purified by column chromatography (SP: silica gel), eluting with $\mathrm{CH}_{2} \mathrm{Cl}_{2} /$ methanol $99: 1$ (v/v) or by preparative chromatography (SP: silica gel), eluting with $\mathrm{CH}_{2} \mathrm{Cl}_{2} /$ methanol 95:5 (v/v).

1-(Benzo[b] thiophen-3-yl)-3-[4-(4-nitro-2-trifluoromethylphenyl)piperazin-1-yl]propan-1-ona

Yield 3\%; Mp 140-141 ${ }^{\circ} \mathrm{C} ;{ }^{1} \mathrm{H}-\mathrm{NMR}\left(\mathrm{CDCl}_{3}\right): \delta$ 2.76-2.77 (m, 4H, $\mathbf{H}_{2}+\mathbf{H}_{6}$ piperazine); $3.02(\mathrm{c}, 2 \mathrm{H}$, $\mathrm{CO}-\mathrm{CH}_{2}-\mathrm{CH}_{2}$ ); 3.19-3.21 (t, $4 \mathrm{H}, \mathbf{H}_{3}+\mathbf{H}_{5}$ piperazine); 3.27-3.30 (c, $\left.1 \mathrm{H}, \mathrm{CO}-\mathrm{CH}_{2}-\mathrm{CH}_{2}\right) ; 7.29$ (dd, $1 \mathrm{H}$, $\mathbf{H}_{6}$, phenyl, $\left.J_{6^{\prime}, 5^{\prime}}=9.4 \mathrm{~Hz}, J_{6^{\prime}, 3^{\prime}}=2.5 \mathrm{~Hz}\right) ; 7.46\left(\mathrm{t}, 1 \mathrm{H}, \mathbf{H}_{6}\right.$ benzothiophenyl, $\left.J_{6,5}=8.0 \mathrm{~Hz}\right) ; 7.52(\mathrm{t}, 1 \mathrm{H}$, $\mathbf{H}_{\mathbf{5}}$ benzothiophenyl, $\left.J_{5,4}=8.1 \mathrm{~Hz}\right) ; 7.90\left(\mathrm{~d}, 1 \mathrm{H}, \mathbf{H}_{4}\right.$ benzothiophenyl, $\left.J_{4,5}=8.0 \mathrm{~Hz}\right) ; 8.33-8.36(\mathrm{~m}, 2 \mathrm{H}$, $\mathbf{H}_{5}$, phenyl $+\mathbf{H}_{7}$ benzothiophenyl); 8.53 (s, 1H, $\mathbf{H}_{2}$ benzothiophenyl); 8.78 (d, 1H, $\mathbf{H}_{3}$, phenyl) ppm; Anal. Calcd. for $\left(\mathrm{C}_{22} \mathrm{H}_{20} \mathrm{~N}_{3} \mathrm{~F}_{3} \mathrm{O}_{3} \mathrm{~S}\right) \mathrm{C}, 57.02 ; \mathrm{H}, 4.32 ; \mathrm{N}, 9.07$. Found: C, 56.80; H, 4.53; N, 9.06.

1-(Benzo[b] thiophen-3-yl)-3-[3-(4-nitro-2-trifluoromethylphenylamino)-(R)-pyrrolidin-1-yl] propan1-one (7). Yield 5\%; Mp 98-100 ${ }^{\circ} \mathrm{C} ;{ }^{1} \mathrm{H}-\mathrm{NMR}\left(\mathrm{CDCl}_{3}\right): \delta 1.76-1.83$ (m, $1 \mathrm{H}, \mathbf{H}_{4 \mathrm{ec}}$ pyrrolidine); 2.40 2.48 ( $\mathrm{m}, 1 \mathrm{H}, \mathbf{H}_{4 \mathbf{a x}}$ pyrrolidine); 2.60 (dd, 1H, $\mathbf{H}_{5 \mathbf{a x}}$ pyrrolidine); 2.80 (dd, 1H, $\mathbf{H}_{\text {2ec }}$ pyrrolidine); 2.93 (dd, 1H, $\mathbf{H}_{2 \mathbf{a x}}$ pyrrolidine); 3.00-3.10 (m, 3H, $\mathbf{H}_{5 \text { ec }}$ pyrrolidine $\left.+\mathrm{CO}-\mathrm{CH}_{2}-\mathrm{CH}_{2}\right) ; 3.27$ (t, 2H, CO-CH , $J_{\mathrm{CH} 2-\mathrm{CH} 2}=6.8 \mathrm{~Hz}$ ); 4.16 (s.a, $1 \mathrm{H}, \mathbf{H}_{3}$ pyrrolidine); 5.37 (d, 1H, NH); 6.68 (d, 1H, $\mathbf{H}_{6}$, phenyl, $J_{6},{ }_{5},=9.3$ $\mathrm{Hz}) ; 7.45\left(\mathrm{dd}, 1 \mathrm{H}, \mathbf{H}_{5}\right.$ benzothiophenyl, $\left.J_{5,6}=7.1 \mathrm{~Hz}, J_{5,4}=8.0 \mathrm{~Hz}, J_{57}=1.1 \mathrm{~Hz}\right) ; 7.51\left(\mathrm{dd}, 1 \mathrm{H}, \mathbf{H}_{6}\right.$ benzothiophenyl, $\left.J_{6,5}=7.2 \mathrm{~Hz}, J_{6,7}=8.2 \mathrm{~Hz}, J_{6,4}=1.1 \mathrm{~Hz}\right) ; 7.88\left(\mathrm{dd}, 1 \mathrm{H}, \mathbf{H}_{4}\right.$ benzothiophenyl, $J_{4,5}=$ $\left.8.0 \mathrm{~Hz}, J_{46}=1.0 \mathrm{~Hz}\right) ; 8.22\left(\mathrm{dd}, 1 \mathrm{H}, \mathbf{H}_{5}\right.$, phenyl, $\left.J_{5}, 6^{\prime}=9.3 \mathrm{~Hz}, J_{5^{\prime}, 3},=2.3 \mathrm{~Hz}\right) ; 8.36\left(\mathrm{~s}, 1 \mathrm{H}, \mathbf{H}_{2}\right.$ benzothiophenyl); 8.39 (d, $1 \mathrm{H}, \mathbf{H}_{3}$, phenyl, $\left.J_{3^{\prime}, 5}=2.5 \mathrm{~Hz}\right) ; 8.77$ (dd, $1 \mathrm{H}, \mathbf{H}_{7}$ benzothiophenyl, $J_{7,6}=$ 
$\left.8.2 \mathrm{~Hz}, J_{7,5}=1.0 \mathrm{~Hz}\right)$ ppm; Anal. Calcd. for $\left(\mathrm{C}_{22} \mathrm{H}_{20} \mathrm{~N}_{3} \mathrm{~F}_{3} \mathrm{O}_{3} \mathrm{~S}\right) \mathrm{C}, 57.02 ; \mathrm{H}, 4.32 ; \mathrm{N}, 9.07$. Found: C, 56.72; H, 4.32; N, 9.22.

1-(Benzo[b] thiophen-3-yl)-3-[1-(4-nitrophenyl)piperidin-4-ylamino]propan-1-one (8). Yield 57\%; Mp 144-145 ${ }^{\circ} \mathrm{C}$; ${ }^{1} \mathrm{H}-\mathrm{NMR}$ (DMSO-d ${ }_{6}$ ): $\delta 1.22-1.31$ (m, 2H, $\mathbf{H}_{3 \mathbf{a x}}+\mathbf{H}_{5 \mathbf{a x}}$ piperidine); 1.79 (bs, $1 \mathrm{H}, \mathrm{NH}$ ); $1.78\left(\mathrm{dd}, 2 \mathrm{H}, \mathbf{H}_{3 \mathbf{3 e c}}+\mathbf{H}_{5 \mathrm{ec}}\right.$ piperidine); 2.71-2.78 (m, 1H, $\mathbf{H}_{4}$ piperidine); 2.95 (t, 2H, CO-CH $\mathbf{H}_{2}, J_{\mathrm{CH} 2-\mathrm{CH} 2}$ $=6.6 \mathrm{~Hz}) ; 3.05-3.11\left(\mathrm{~m}, 2 \mathrm{H}, \mathbf{H}_{2 \mathbf{2 a x}}+\mathbf{H}_{6 \mathbf{a x}}\right.$ piperidine); $3.18\left(\mathrm{t}, 2 \mathrm{H}, \mathrm{CH}_{2}-\mathrm{NH}, J_{\mathrm{CH} 2-\mathrm{CH} 2}=6.6 \mathrm{~Hz}\right) ; 3.92(\mathrm{~d}$, $2 \mathrm{H}, \mathbf{H}_{2 \mathrm{ec}}+\mathbf{H}_{6 \mathrm{6ec}}$ piperidine); $7.00\left(\mathrm{~d}, 2 \mathrm{H}, \mathbf{H}_{2},+\mathbf{H}_{\mathbf{6}}\right.$, phenyl, $\left.J_{2^{\prime}, 3^{\prime}}=J_{6^{\prime}, 5},=9.6 \mathrm{~Hz}\right) ; 7.43-7.52\left(\mathrm{~m}, 2 \mathrm{H}, \mathbf{H}_{5}\right.$ $+\mathbf{H}_{6}$ benzothiophenyl); $8.02\left(\mathrm{~d}, 2 \mathrm{H}, \mathbf{H}_{3^{\prime}}, \mathbf{H}_{5^{\prime}}\right.$ phenyl, $\left.J_{3^{\prime}, 2^{\prime}}=J_{5^{\prime}, 6^{\prime}}=9.5 \mathrm{~Hz}\right) ; 8.08\left(\mathrm{~d}, 1 \mathrm{H}, \mathbf{H}_{4}\right.$ benzothiophenyl); 8.61 (d, 1H, $\mathbf{H}_{7}$ benzothiophenyl); $8.97\left(\mathrm{~s}, 1 \mathrm{H}, \mathbf{H}_{2}\right)$ ppm; Anal. Calcd. for $\left(\mathrm{C}_{22} \mathrm{H}_{23} \mathrm{~N}_{3} \mathrm{O}_{3} \mathrm{~S}\right) \mathrm{C}, 64.53 ; \mathrm{H}, 5.66 ; \mathrm{N}, 10.26$. Found: $\mathrm{C}, 64.88 ; \mathrm{H}, 5.67 ; \mathrm{N}, 10.28$.

Hydrochloride of 1-(benzo[b] thiophen-3-yl)-3-[4-(4-nitrophenyl)-1,4-diazepan-1-yl]propan-1-one (9). Yield 57\%; Mp 121-123 ${ }^{\circ} \mathrm{C} ;{ }^{1} \mathrm{H}-\mathrm{NMR}$ (DMSO-d ) $_{\text {) } \delta}$ 2.22-2.28 (m, 1H, $\mathbf{H}_{6}$ diazepane); 2.43-246 (m, $1 \mathrm{H}, \mathbf{H}_{6}$ diazepane); 3.20-3.25 (m, 2H, $\mathbf{H}_{7}$ diazepane); 3.35 (m, 2H, CO-CH$\left.-\mathrm{CH}_{2}\right)$; 3.53-3.56 (m, 2H, $\mathbf{H}_{2}$ diazepane); 3.63-3.67 (m, 2H, $\mathbf{H}_{5}$ diazepane); 3.70-3.72 (m, 2H, CO-CH $)$; 3.87-3.95 (m, $1 \mathrm{H}, \mathbf{H}_{3}$ diazepane); 4.03-4.09 (m, 1H, $\mathbf{H}_{3}$ diazepane); 6.92(d, 2H, $\mathbf{H}_{2},+\mathbf{H}_{6}$, phenyl, $\left.J_{2}{ }^{\prime},{ }^{\prime}=J_{6}, 5,=9.4 \mathrm{~Hz}\right)$; 7.46-7.55 (m, 2H, $\mathbf{H}_{6}+\mathbf{H}_{\mathbf{5}}$ benzothiophenyl); 8.08-8.12 (m, 3H, $\mathbf{H}_{\mathbf{4}}$ benzothiophenyl+ $\mathbf{H}_{\mathbf{3}}{ }^{\prime}+\mathbf{H}_{5}{ }^{\prime}$ phenyl); 8.60 (d, 1H, $\mathbf{H}_{7}$ benzothiophenyl, $J_{7,6}=8.1 \mathrm{~Hz}$ ); 9.06 (s,1H, $\mathbf{H}_{2}$ benzothiophenyl); 10.95 (s.a., $1 \mathrm{H}, \mathrm{HCl})$ ppm; Anal. Calcd. for $\left(\mathrm{C}_{22} \mathrm{H}_{23} \mathrm{~N}_{3} \mathrm{O}_{3} \mathrm{~S} \cdot \mathrm{HCl}\right) \mathrm{C}$, 59.25; H, 5.42; N, 9.42. Found: C, 58.86; H, $5.69 ; \mathrm{N}, 9.08$.

1-(Benzo[b]thiophen-3-yl)-3-[4-(quinoxalin-2-yl)piperazin-1-yl]propan-1-one (10). Yield 13\%; Mp 145-146 ${ }^{\circ} \mathrm{C} ;{ }^{1} \mathrm{H}-\mathrm{NMR}\left(\mathrm{CDCl}_{3}\right): \delta 2.74\left(\mathrm{t}, 4 \mathrm{H}, \mathbf{H}_{2}+\mathbf{H}_{6}\right.$ piperazine); $3.00\left(\mathrm{t}, 2 \mathrm{H}, \mathrm{CO}-\mathrm{CH}_{2}-\mathrm{CH}_{2}\right) ; 3.08$ (t, $\left.2 \mathrm{H}, \mathrm{CO}-\mathrm{CH}_{2}\right) ; 3.85\left(\mathrm{t}, 4 \mathrm{H}, \mathbf{H}_{3}+\mathbf{H}_{5}\right.$ piperazine); 7.40-7.47 (m, $2 \mathrm{H}, \mathbf{H}_{5}$ benzothiophenyl $+\mathbf{H}_{7}$, quinoxalinyl); 7.53 (dd, $1 \mathrm{H}, \mathbf{H}_{6}$ benzothiophenyl, $\left.J_{6,5}=8.3 \mathrm{~Hz}, J_{6,7}=7.1 \mathrm{~Hz}, J_{6,4}=1.2 \mathrm{~Hz}\right) ; 7.60(\mathrm{~m}$, $1 \mathrm{H}, \mathbf{H}_{6}$, quinoxalinyl); $7.71\left(\mathrm{dd}, 1 \mathrm{H}, \mathbf{H}_{5}\right.$, quinoxalinyl, $\left.J_{5^{\prime}, 6^{\prime}}=8.4 \mathrm{~Hz}, J_{5^{\prime}, 7},=1.3 \mathrm{~Hz}\right) ; 7.91\left(\mathrm{~m}, 2 \mathrm{H}, \mathbf{H}_{\mathbf{8}^{\prime}}\right.$, quinoxalinyl $+\mathbf{H}_{\mathbf{4}}$ benzothiophenyl); $8.38\left(\mathrm{~s}, 1 \mathrm{H}, \mathbf{H}_{\mathbf{2}}\right.$ benzothiophenyl); 8.60 (s, 1 $\mathrm{H}, \mathbf{H}_{3}$,quinoxalinyl); 8.79 (dd, $1 \mathrm{H}, \mathbf{H}_{7}$ benzothiophenyl, $\left.J_{7,6}=8.2 \mathrm{~Hz}, J_{7,5}=0.7 \mathrm{~Hz}\right)$ ppm; Anal. Calcd. for $\left(\mathrm{C}_{23} \mathrm{H}_{22} \mathrm{~N}_{4} \mathrm{OS}\right) \mathrm{C}$, 68.63; H, 5.51; N, 13.92. Found: C, 68.58; H, 5.42; N, 13.77 .

Dihydrochloride of 1-(5-fluorobenzo[b]thiophen-3-yl)-3-[4-(3-methoxyphenyl)piperazin-1-yl]propan-


3.16 (m, 4H, $\mathbf{2 H}_{2}+\mathbf{2 H}_{\mathbf{6}}$ piperazine); 3.28-3.33 (m, 2H, $\left.\mathrm{CHCH}_{2} \mathrm{CH}_{2}\right) ; 3.56-3.58$ (m, 2H, $\mathbf{1 H}_{\mathbf{3 e c}}+\mathbf{1 H}_{\mathbf{5 e c}}$ piperazine); 3.73 (s, 3H, OCH $)$; 3.79-3.82 (m, 2H, $\mathbf{H}_{3 \mathbf{a x}}+\mathbf{H}_{5 \mathrm{ax}}$ piperazine); 4.52 (bs, 1H, OH); 5.03 (t, $\left.1 \mathrm{H}, \mathrm{CHOH}, J_{\mathrm{CH}-\mathrm{CH} 2}=7.6 \mathrm{~Hz}\right) ; 6.44\left(\mathrm{~d}, 1 \mathrm{H}, \mathbf{H}_{4}\right.$, phenyl, $\left.J_{4^{\prime}, 5},=8.0 \mathrm{~Hz}, J_{4^{\prime}, 6^{\prime}}=2.0 \mathrm{~Hz}\right) ; 6.46\left(\mathrm{~s}, 1 \mathrm{H}, \mathbf{H}_{2}\right.$, phenyl); 6.52 (d, $1 \mathrm{H}, \mathbf{H}_{6}$, phenyl, $\left.J_{6^{\prime}, 5^{\prime}}=8.0 \mathrm{~Hz}, J_{6^{\prime}, 4^{\prime}}=2.0 \mathrm{~Hz}\right) ; 7.13\left(\mathrm{t}, 1 \mathrm{H}, \mathbf{H}_{5}\right.$, phenyl, $J_{5^{\prime}, 6^{\prime}}=J_{5^{\prime}, 4^{\prime}}=$ $8.4 \mathrm{~Hz}) ; 7.27\left(\mathrm{t}, 1 \mathrm{H}, \mathbf{H}_{6}\right.$ benzothiophenyl, $\left.J_{6,7}=8.8 \mathrm{~Hz}, J_{6,4}=2.4 \mathrm{~Hz}\right) ; 7.77\left(\mathrm{~s}, 1 \mathrm{H}, \mathbf{H}_{2}\right.$ benzothiophenyl); 7.81 (d, $1 \mathrm{H}, \mathbf{H}_{7}$ benzothiophenyl, $J_{7,6}=8.8 \mathrm{~Hz}$ ); 8.03 (dd, 1H, $\mathbf{H}_{4}$ benzothiophenyl, $J=8.8 \mathrm{~Hz})$ ); $10.91(\mathrm{~s}, 1 \mathrm{H}, \mathrm{OH})$; ppm; Anal. Calcd. for $\left(\mathrm{C}_{22} \mathrm{H}_{25} \mathrm{FN}_{2} \mathrm{O}_{2} \mathrm{~S} .2 \mathrm{HCl}\right) \mathrm{C}, 55.81 ; \mathrm{H}, 5.70 ; \mathrm{N}$, 5.91. Found: C, 55.41; H, 5.82; N, 5.43. 
1-(Benzo[b] thiophen-3-yl)-3-[4-(4-nitro-2-trifluoromethylphenyl)piperazin-1-yl]propan-1-ol

Yield 3\%; Mp 154-155 ${ }^{\circ} \mathrm{C} ;{ }^{1} \mathrm{H}-\mathrm{NMR}\left(\mathrm{CDCl}_{3}\right)$ : 2.14-2.16 (m, 2H, CHOH-CH$) ; 2.77-2.87$ (m, 6H, $\mathrm{CHOH}-\mathrm{CH}_{2}-\mathrm{CH}_{2}+\mathbf{H}_{2}+\mathbf{H}_{6}$ piperazine); 3.20-3.29 (m, 4H, $\mathbf{H}_{3}+\mathbf{H}_{5}$ piperazine); 5.38 (t, 1H, $\mathrm{CHOH}$, $\left.J_{\mathrm{CH}-\mathrm{CH} 2}=7.5 \mathrm{~Hz}\right) ; 7.33-7.42\left(\mathrm{~m}, 3 \mathrm{H}, \mathbf{H}_{6}\right.$, phenyl $+\mathbf{H}_{6}+\mathbf{H}_{5}$ benzothiophenyl); $7.45\left(\mathrm{~s}, 1 \mathrm{H}, \mathbf{H}_{2}\right.$ benzothiophenyl); $7.82\left(\mathrm{~d}, 1 \mathrm{H}, \mathbf{H}_{4}\right.$ benzothiophenyl, $\left.J_{4,5}=8.4 \mathrm{~Hz}\right) ; 7.88$ (d, 1H, $\mathbf{H}_{7}$ benzothiophenyl, $\left.J_{7,6}=8.0 \mathrm{~Hz}\right) ; 8.37\left(\mathrm{dd}, 1 \mathrm{H}, \mathbf{H}_{5}\right.$, phenyl $\left.J_{5}{ }^{\prime},{ }^{\prime}=9.2 \mathrm{~Hz}, J_{5}{ }^{,}, 3=2.8 \mathrm{~Hz}\right) ; 8.55\left(\mathrm{~d}, 1 \mathrm{H}, \mathbf{H}_{3}\right.$, phenyl) ppm; Anal. Calcd. for $\left(\mathrm{C}_{22} \mathrm{H}_{22} \mathrm{~N}_{3} \mathrm{~F}_{3} \mathrm{O}_{3} \mathrm{~S}\right) \mathrm{C}, 57.77 ; \mathrm{H}, 4.73 ; \mathrm{N}, 9.03$. Found: C, 57.01; H, 4.85; N, 8.54.

1-(Benzo[b] thiophen-3-yl)-3-[3-(4-nitro-2-trifluoromethylphenylamino)-(R)-pyrrolidin-1-yl]propan-1ol (29). Yield 47\%; Mp 48-50 ${ }^{\circ} \mathrm{C}$; ${ }^{1} \mathrm{H}-\mathrm{NMR}$ (DMSO- $\mathrm{d}_{6}$ ): $\delta 1.82-1.89$ (m, 1H, $\mathbf{H}_{4 \mathbf{4 e c}}$ pyrrolidine); 2.06$2.21\left(\mathrm{~m}, 2 \mathrm{H}, \mathrm{CHOH}-\mathrm{CH}_{2}\right) ; 2.47-2.56\left(\mathrm{~m}, 1 \mathrm{H}, \mathbf{H}_{4 \mathbf{a x}}\right.$ pyrrolidine $) ; 2.76-2.85\left(\mathrm{~m}, 3 \mathrm{H}, \mathrm{CHOH}-\mathrm{CH}_{2}-\mathrm{CH}_{2}+\right.$ $\mathbf{H}_{\text {2ec }}+\mathbf{H}_{5 \text { ax }}$ pyrrolidine); 3.00-3.15 (m, 2H, CHOH-CH $-\mathrm{CH}_{2}+\mathbf{H}_{5 \mathbf{e c}}$ pyrrolidine); 3.07-3.11 (m, 1H, $\mathbf{H}_{2 a x}$ pyrrolidine); 4.18-4.26 (m, 1H, $\mathbf{H}_{3}$ pyrrolidine); 5.27 (bs, $\left.1 \mathrm{H}, \mathrm{NH}\right) ; 5.36-5.38$ (m, 1H, CHOH); $6.72\left(\mathrm{dd}, 1 \mathrm{H}, \mathbf{H}_{\mathbf{6}^{\prime}}\right.$, phenyl, $\left.J_{6^{\prime}, 5}{ }^{\prime}=9.3 \mathrm{~Hz}, J_{6^{\prime}, 3^{\prime}}=2.3 \mathrm{~Hz}\right) ; 7.34-7.40$ (m, 2H, $\mathbf{H}_{5}, \mathbf{H}_{6}$ benzothiophenyl); 7.44 (d, 1H, $\mathbf{H}_{2}$ benzothiophenyl, $J=7.3 \mathrm{~Hz}$ ); 7.80-7.83 (m, 1H, $\mathbf{H}_{\mathbf{4}}$ benzothiophenyl); 7.87-7.90 (m, $1 \mathrm{H}, \mathbf{H}_{7}$ benzothiophenyl); $8.29\left(\mathrm{dd}, 1 \mathrm{H}, \mathbf{H}_{5}\right.$, phenyl, $\left.J_{5^{\prime}, 6^{\prime}}=9.4 \mathrm{~Hz}, J_{5^{\prime}, 3^{\prime}}=2.2 \mathrm{~Hz}\right) ; 8.44\left(\mathrm{t}, 1 \mathrm{H}, \mathbf{H}_{3^{\prime}}\right.$, phenyl, $\left.J_{3^{\prime}, \mathrm{F}}=J_{3^{\prime}, 5^{\prime}}=2.9 \mathrm{~Hz}\right)$ ppm; Anal. Calcd. for $\left(\mathrm{C}_{22} \mathrm{H}_{22} \mathrm{~N}_{3} \mathrm{~F}_{3} \mathrm{O}_{3} \mathrm{~S}\right) \mathrm{C}, 56.77 ; \mathrm{H}, 4.76 ; \mathrm{N}, 9.07$. Found: C56.50; H, 4.88; N, 9.02.

1-(Benzo[b] thiophen-3-yl)-3-[1-(4-nitro-2-trifluoromethylphenyl)-(S)-pyrrolidin-3-ylamino]propan-1ol (30). Yield 18\%; Mp 109-110 ${ }^{\circ} \mathrm{C}$; . ${ }^{1} \mathrm{H}-\mathrm{NMR}\left(\mathrm{CDCl}_{3}\right): \delta$ 1.94-2.07 (m, 2H, CHOH-CH 2$) ; 2.15-2.20$ (m, 1H, $\mathbf{H}_{4 \text { ec }}$ pyrrolidine); 2.24-2.31 (m, 1H, $\mathbf{H}_{4 \mathbf{a x}}$ pyrrolidine); 2.91-3.00 (m, 1H, CHOH-CH $-\mathrm{CH}_{2}$ ); 3.04-3.10 (m, 1H, CHOH-CH $\left.-\mathrm{CH}_{2}\right) 3.20$ (bs, 1H, OH); 3.41 (td, 1H, $\mathbf{H}_{2 \mathbf{c e}}$ pyrrolidine); 3.49-3.54 (m, $1 \mathrm{H}, \mathbf{H}_{5 \mathrm{ec}}$ pyrrolidine); 3.58-3.65 (m, $1 \mathrm{H}, \mathbf{H}_{2 \mathbf{a x}}$ pyrrolidine); 3.72-3.80 (m, 2H, $\mathbf{H}_{5 \mathbf{a x}}+\mathbf{H}_{3}$ pyrrolidine); 5.35 (bs, $1 \mathrm{H}, \mathbf{C H O H}) ; 6.84\left(\mathrm{dd}, 1 \mathrm{H}, \mathbf{H}_{6^{\prime}}, J_{6^{\prime}, 5},=9.5 \mathrm{~Hz}, \mathbf{H}_{6}\right.$, phenyl, $\left.J_{6^{\prime}, 3},=2.5 \mathrm{~Hz}\right) ; 7.33-7.43(\mathrm{~m}, 3 \mathrm{H}$, $\mathbf{H}_{5}+\mathbf{H}_{6}+\mathbf{H}_{2}$ benzothiophenyl); 7.77-7.80 (m, 1H, $\mathbf{H}_{\mathbf{4}}$ benzothiophenyl); 7.87-7.89 (m, 1H, $\mathbf{H}_{7}$ benzothiophenyl); 8.18-8.22 (m, $1 \mathrm{H}, \mathbf{H}_{5}$, phenyl); $8.58\left(\mathrm{dd}, 1 \mathrm{H}, \mathbf{H}_{3}\right.$, phenyl, $J_{3^{\prime}, 5^{\prime}}=5.1 \mathrm{~Hz}, J_{3^{\prime}, 6^{\prime}}=2.6$ $\mathrm{Hz})$ ppm; Anal. Calcd. for $\left(\mathrm{C}_{22} \mathrm{H}_{22} \mathrm{~N}_{3} \mathrm{~F}_{3} \mathrm{O}_{3} \mathrm{~S}\right) \mathrm{C}, 56.77 ; \mathrm{H}, 4.76 ; \mathrm{N}, 9.07$. Found: $\mathrm{C}, 56.33 ; \mathrm{H}, 4.94 ; \mathrm{N}$, 9.06 .

1-(Benzo[b] thiophen-3-yl)-3-[1-(4-nitro-2-trifluoromethylphenyl)piperidin-4-ylamino]propan-1-ol (31). Yield 33\%; Mp 145-146 ${ }^{\circ} \mathrm{C} ;{ }^{1} \mathrm{H}-\mathrm{NMR}\left(\mathrm{CDCl}_{3}\right): \delta 1.57-1.68\left(\mathrm{~m}, 2 \mathrm{H}, \mathbf{H}_{3 \mathbf{a x}}+\mathbf{H}_{5 \mathbf{a x}}\right.$ piperidine); 1.94-2.03 (m, 1H, CHOH-CH $)$; 2.08 (d, 2H, $\mathbf{H}_{3 \mathbf{e c}}+\mathbf{H}_{5 \mathbf{e c}}$ piperidine); 2.15-2.20 (m, 1H, CHOH-CH 2 ); 2.71-2.77 (m, 1H, $\mathbf{H}_{4}$ piperidine); 2.91-3.01 (m, 3H, $\mathbf{H}_{2 \mathbf{a x}}+\mathbf{H}_{6 \mathbf{a x}}$ piperidine $\left.+\mathrm{CH}_{2}-\mathrm{NH}\right) ; 3.07-3.12(\mathrm{~m}$, 1H, $\left.\mathbf{C H}_{2}-\mathrm{NH}\right) ; 3.41$ (d, 2H, $\mathbf{H}_{2 \mathbf{2 e c}}+\mathbf{H}_{6 \mathbf{6 e c}}$ piperidine); 5.38 (m, 1H, CHOH); 7.27 (d, 1H, $\mathbf{H}_{6}$, phenyl, $J_{6}, 5^{\prime}=8.9 \mathrm{~Hz}$ ); 7.34-7.40 (m, 2H, $\mathbf{H}_{5}+\mathbf{H}_{6}$ benzothiophenyl); 7.46 (s, 1H, $\mathbf{H}_{2}$ benzothiophenyl); 7.81 $\left(\mathrm{d}, 1 \mathrm{H}, \mathbf{H}_{4}\right.$, benzothiophenyl $\left.J_{4,5}=7.9 \mathrm{~Hz}\right) ; 7.88\left(\mathrm{~d}, 1 \mathrm{H}, \mathbf{H}_{7}\right.$ benzothiophenyl, $\left.J_{7,6}=7.8 \mathrm{~Hz}\right) ; 8.32(\mathrm{dd}$, $1 \mathrm{H}, \mathbf{H}_{5}$, phenyl, $\left.J_{5^{\prime}, 6^{\prime}}=9.0 \mathrm{~Hz}, J_{5^{\prime}, 3^{\prime}}=2.3 \mathrm{~Hz}\right) ; 8.53\left(\mathrm{~d}, 1 \mathrm{H}, \mathbf{H}_{3}\right.$, phenyl, $\left.J_{3^{\prime}, 5^{\prime}}=2.4 \mathrm{~Hz}\right) \mathrm{ppm}$; Anal. Calcd. for $\left(\mathrm{C}_{23} \mathrm{H}_{24} \mathrm{~N}_{3} \mathrm{~F}_{3} \mathrm{O}_{3} \mathrm{~S}\right) \mathrm{C}, 57.61 ; \mathrm{H}, 5.04 ; \mathrm{N}, 8.76$. Found: C, 57.39; H, 5.06; N, 8.80.

1-(5-Fluorobenzo[b] thiophen-3-yl)-3-[4-(4-nitrophenyl)piperazin-1-yl]propan-1-ol (32). Yield 14\%; Mp 189-190 ${ }^{\circ} \mathrm{C} ;{ }^{1} \mathrm{H}-\mathrm{NMR}\left(\mathrm{CDCl}_{3}\right): \delta 1.60$ (bs, 1H, OH); 2.10-2.15 (m, 2H, CHOH-CH $)$; 2.79-2.90 
(m, 6H, CHOH-CH$-\mathrm{CH}_{2}+\mathbf{H}_{2}+\mathbf{H}_{6}$ piperazine); 3.53 (t, 4H, $\mathbf{H}_{3}+\mathbf{H}_{5}$ piperazine); 5.30 (dd, 1H, $\mathrm{CHOH}) ; 6.88\left(\mathrm{~d}, 2 \mathrm{H}, \mathbf{H}_{2},+\mathbf{H}_{6}\right.$, phenyl, $\left.J_{2}{ }^{,},{ }^{\prime}=J_{6},{ }_{5},=9.4 \mathrm{~Hz}\right) ; 7.14\left(\mathrm{td}, 1 \mathrm{H}, \mathbf{H}_{6}\right.$ benzothiophenyl, $J_{6,7}=$ $\left.J_{6, \mathrm{~F}}=8.7 \mathrm{~Hz}, J_{6,4}=2.4 \mathrm{~Hz}\right) ; 7.50-7.53\left(\mathrm{~m}, 2 \mathrm{H}, \mathbf{H}_{2}+\mathbf{H}_{\mathbf{4}}\right.$ benzothiophenyl); $7.81\left(\mathrm{dd}, 1 \mathrm{H}, \mathbf{H}_{7}\right.$ benzothiophenyl, $\left.J_{7,6}=8.8 \mathrm{~Hz}, J_{7, \mathrm{~F}}=4.8 \mathrm{~Hz}\right) ; 8.17\left(\mathrm{~d}, 2 \mathrm{H}, \mathbf{H}_{3}{ }^{\prime}+\mathbf{H}_{5}{ }^{\prime}\right.$ phenyl, $\left.J_{3^{\prime}, 4^{\prime}}=J_{5^{\prime}, 6^{\prime}}=9.4 \mathrm{~Hz}\right)$ ppm; Anal. Calcd. for $\left(\mathrm{C}_{21} \mathrm{H}_{22} \mathrm{~N}_{3} \mathrm{FO}_{3} \mathrm{~S}\right) \mathrm{C}, 60.71 ; \mathrm{H}, 5.34 ; \mathrm{N}, 10.11$. Found: $\mathrm{C}, 60.44 ; \mathrm{H}, 5.43 ; \mathrm{N}, 9.79$.

1-(Benzo[b] thiophen-3-yl)-3-(1-(4-nitrophenyl)piperidin-4-ylamino)propan-1-ol (33). Yield 57\%; Mp 153-155 ${ }^{\circ} \mathrm{C} ;{ }^{1} \mathrm{H}-\mathrm{NMR}$ (DMSO-d 6 ): $\delta 1.23-1.31$ (m, 2H, $\mathbf{H}_{3 \mathbf{a x}}+\mathbf{H}_{5 \mathbf{a x}}$ piperidine); 1.86-1.96 (m, 4H, $\mathbf{H}_{3 \mathbf{e c}}$ $+\mathbf{H}_{5 e c}$ piperidine $\left.+\mathrm{CHOH}-\mathrm{CH}_{2}\right) ; 2.69-2.73\left(\mathrm{~m}, 3 \mathrm{H}, \mathbf{H}_{2 \mathbf{a x}}+\mathbf{H}_{6 \mathbf{a x}}+\mathbf{H}_{4}\right.$ piperidine); 3.07 (t, 2H, $\mathrm{CH}_{2^{-}}$ $\mathrm{NH}$ ); 3.95 (d, 2H, $\mathbf{H}_{2 \mathbf{2 e c}}+\mathbf{H}_{\mathbf{6 e c}}$ piperidine); 5.08 (s.a., 1H, CHOH); 7.27 (d, 1H, $\mathbf{H}_{2},+\mathbf{H}_{6}$, phenyl, $J_{2}{ }^{,}, 3^{,}=$ $J_{6}, 5^{\prime}=8.7 \mathrm{~Hz}$ ); 7.33-7.39 (m, 2H, $\mathbf{H}_{5}+\mathbf{H}_{6}$ benzothiophenyl); 7.53 (s, 1H, $\mathbf{H}_{2}$ benzothiophenyl); 7.93$7.97\left(\mathrm{~m}, 2 \mathrm{H}, \mathbf{H}_{4}+\mathbf{H}_{7}\right.$ benzothiophenyl); $8.32\left(\mathrm{dd}, 1 \mathrm{H}, \mathbf{H}_{3},+\mathbf{H}_{5}\right.$, phenyl, $\left.J_{3^{\prime}, 2^{\prime}}=J_{5^{\prime}, 6^{\prime}}=8.8 \mathrm{~Hz}\right) \mathrm{ppm}$; Anal. Calcd. for $\left(\mathrm{C}_{22} \mathrm{H}_{25} \mathrm{~N}_{3} \mathrm{O}_{3} \mathrm{~S}\right) \mathrm{C}, 64.21 ; \mathrm{H}, 6.12 ; \mathrm{N}, 10.21$. Found: C, 64.00; H, 5.97; N, 10.43 .

1-(Benzo[b] thiophen-3-yl)-3-(4-(4-nitrophenyl)-1,4-diazepan-1-yl)propan-1-ol (34). Yield 61\%; Mp

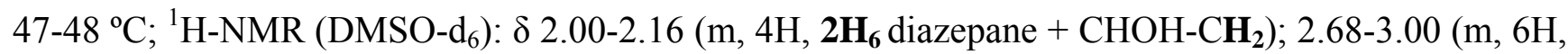
$\mathrm{CH}-\mathrm{CH}_{2}-\mathbf{C H}_{2}+\mathbf{2} \mathbf{H}_{2}+\mathbf{2} \mathbf{H}_{7}$ diazepane); 3.64-3.68 (m, 2H, 2- $\mathbf{H}_{5}$ diazepane); 3.74 (bs, 2H, 2H diazepane); 5.32-5.38 (m, 1H, CHOH); 6.67 (d, 2H, $\mathbf{H}_{2^{\prime}}+\mathbf{H}_{6^{\prime}}$, phenyl, $\left.J_{2^{\prime}, 3^{\prime}}=J_{6^{\prime}, 5^{\prime}}=9.4 \mathrm{~Hz}\right) ;$ 7.36-7.39 (m, 2H, $\mathbf{H}_{\mathbf{6}}+\mathbf{H}_{5}$ benzothiophenyl); 7.43 (s, 1H, $\mathbf{H}_{2}$ benzothiophenyl); 7.78 (d, 1H, $\mathbf{H}_{4,} J_{4,5}=7.42$ benzothiophenyl); 7.88 (d, $1 \mathrm{H}, \mathbf{H}_{7}$ benzothiophenyl, $J_{7,6}=7.03 \mathrm{~Hz}$ ); $8.15\left(\mathrm{~d}, 2 \mathrm{H}, \mathbf{H}_{3}, \mathbf{H}_{5}\right.$, phenyl, $J_{3^{\prime}, 2^{\prime}}$ $\left.=J_{5}, 6^{\prime}=9.0 \mathrm{~Hz}\right)$ ppm; Anal. Calcd. for $\left(\mathrm{C}_{22} \mathrm{H}_{25} \mathrm{~N}_{3} \mathrm{O}_{3} \mathrm{~S}\right) \mathrm{C}, 65.23 ; \mathrm{H}, 6.08 ; \mathrm{N}, 10.22$. Found: C, 65.44; H, 6.45; N, 9.79.

1-(Benzo[b] thiophen-3-yl)-3-(4-(quinoxalin-2-yl)piperazin-1-yl)propan-1-ol (35). Yield 15\%; Mp 155-156 ${ }^{\circ} \mathrm{C} ;{ }^{1} \mathrm{H}-\mathrm{NMR}\left(\mathrm{DMSO}-\mathrm{d}_{6}\right): \delta 2.29-2.32\left(\mathrm{~m}, 2 \mathrm{H}, \mathrm{CHOHCH}_{2}\right) ; 3.13-3.22\left(\mathrm{~m}, 6 \mathrm{H}, \mathrm{CH}-\mathrm{CH}_{2}-\mathrm{CH}_{2}\right.$ $+2 \mathbf{H}_{2}+2 \mathbf{H}_{6}$ piperazine); 3.46-3.54 (m, 2H, $\mathbf{H}_{3}$ piperazine); 3.56-3.64 (m, 2H, $\mathbf{H}_{5}$ piperazine); 5.055.07 (m, 1H, CHOH); 5.76 (bs, 1H, OH); 7.37-7.44 (m, 2H, $\mathbf{H}_{5}+\mathbf{H}_{\mathbf{6}}$ benzothiophenyl); 7.45-7.49 (m, $1 \mathrm{H}, \mathbf{H}_{7}$, quinoxalinyl); 7.63-7.66 (m, 3H, $\mathbf{H}_{2}+\mathbf{H}_{\mathbf{4}}$ benzothiophenyl $+\mathbf{H}_{6}$, quinoxalinyl); $8.88(\mathrm{~d}, 1 \mathrm{H}$, $\mathbf{H}_{7}$ benzothiophenyl, $\left.J_{7,6}=8.4\right) ; 7.99\left(\mathrm{dd}, 2 \mathrm{H}, \mathbf{H}_{5},+\mathbf{H}_{8}\right.$, quinoxalinyl, $J_{5^{\prime}, 6^{\prime}}=J_{8^{\prime}, 7}=8.9 \mathrm{~Hz}, J_{5^{\prime}, 7}{ }^{\prime}=J_{8^{\prime}, 6^{\prime}}=$ $1.2 \mathrm{~Hz}$ ); 8.90 (s, $1 \mathrm{H}, \mathbf{H}_{3}$, quinoxalinyl) ppm; Anal. Calcd. for $\left(\mathrm{C}_{23} \mathrm{H}_{24} \mathrm{~N}_{4} \mathrm{OS}\right) \mathrm{C}, 68.31 ; \mathrm{H}, 5.94 ; \mathrm{N}$, 13.86. Found: C, 68.70; H, 6.22; N, 13.65.

1-(4-Phenyl)phenyl -3-[4-(4-chlorophenyl)piperazin-1-yl]propan-1-ol (38). Yield 47\%; Mp 169-170 ${ }^{\circ} \mathrm{C}$; ${ }^{1} \mathrm{H}-\mathrm{NMR}$ (DMSO-d $)$ ): $\delta$ 1.80-1.85 (m, 2H, CHOHCH ); 3.12-3.16 (m, 6H, CH-CH $-\mathrm{CH}_{2}+2 \mathbf{H}_{2}+$ $2 \mathbf{H}_{6}$ piperazine); 3.34 (bs, $4 \mathrm{H}, 2 \mathbf{H}_{3}+2 \mathbf{H}_{5}$ piperazine); 4.68-4.70 (m, 1H, CHOH); 5.51 (s, 1H, OH); $6.93\left(\mathrm{~d}, 2 \mathrm{H}, \mathbf{H}_{2}+\mathbf{H}_{6}\right.$ Cl-phenyl, $J=9.0 \mathrm{~Hz}$ ); 7.22 (d, 2H, $\mathbf{H}_{3}+\mathbf{H}_{5}$ Cl-phenyl, $\left.J=8.8 \mathrm{~Hz}\right) ; 7.35$ (t, $1 \mathrm{H}, \mathbf{H}_{4}$, phenyl, $J=8.4 \mathrm{~Hz}$ ); 7.31-7.38 (m, 4H, $\mathbf{H}_{2}+\mathbf{H}_{6}$ p-phenylphenyl $+\mathbf{H}_{3},+\mathbf{H}_{5}$, phenyl); 7.61-7.67 (m, 4H, $\mathbf{H}_{3}+\mathbf{H}_{5}$ p-phenylphenyl $+\mathbf{H}_{2},+\mathbf{H}_{6}$, phenyl); ppm; Anal. Calcd. for $\left(\mathrm{C}_{25} \mathrm{H}_{27} \mathrm{ClN}_{2} \mathrm{O}\right) \mathrm{C}, 73.80 ; \mathrm{H}, 6.64 ; \mathrm{N}$, 6.88. Found: C, 73.48; H, 6.89; N, 6.78.

1-(4-Phenyl)phenyl-3-[4-(2-methoxyphenyl)piperazin-1-yl]propan-1-ol (40). Yield 77\% yield; Mp 109-110 ${ }^{\circ} \mathrm{C}$; ${ }^{1} \mathrm{H}-\mathrm{NMR}$ (DMSO-d $\left.)_{6}\right): \delta 1.79-1.83\left(\mathrm{~m}, 2 \mathrm{H}, \mathrm{CHOHCH}_{2}\right) ; 2.38-2.54\left(\mathrm{~m}, 6 \mathrm{H}, \mathrm{CHCH}_{2} \mathrm{CH}_{2}+\right.$ 
$\mathbf{2 H}_{\mathbf{2}}+\mathbf{2} \mathbf{H}_{\mathbf{6}}$ piperazine); $2.96\left(\mathrm{bs}, 4 \mathrm{H}, \mathbf{2} \mathbf{H}_{3}+\mathbf{2} \mathbf{H}_{5}\right.$ piperazine); 3.76 (bs, 3H, OCH $)$; 4.70 (t, 1H, $\mathrm{CHOH}) ; 5.52(\mathrm{bs}, 1 \mathrm{H}, \mathrm{OH}) ; 6.87-6.93\left(\mathrm{~m}, 4 \mathrm{H}, \mathbf{H}_{3}+\mathbf{H}_{4}+\mathbf{H}_{5}+\mathbf{H}_{6} \mathbf{O C H}_{3}-\right.$ phenyl); 7.35 (t, $1 \mathrm{H}, \mathbf{H}_{4}$, phenyl); 7.42-7.48 (m, 4H, $\mathbf{H}_{2}+\mathbf{H}_{6}$ p-phenylphenyl $+\mathbf{H}_{3},+\mathbf{H}_{5}$, phenyl); 7.61-7.67 (m, 4H, $\mathbf{H}_{3}+\mathbf{H}_{5}$ pphenylphenyl $+\mathbf{H}_{2},+\mathbf{H}_{6}$, phenyl); ppm; Anal. Calcd. for $\left(\mathrm{C}_{26} \mathrm{H}_{30} \mathrm{~N}_{2} \mathrm{O}_{2}\right) \mathrm{C}, 77.61 ; \mathrm{H}, 7.46 ; \mathrm{N}, 6.96$. Found: C, 77.58; H, 7.75; N, 6.84.

1-(3-Indolyl)-3-[4-(2-methoxyphenyl)piperazin-1-yl]propan-1-ol (41). Yield 30\% yield; Mp 188-189 ${ }^{\circ} \mathrm{C}$; ${ }^{1} \mathrm{H}-\mathrm{NMR}$ (DMSO-d ${ }_{6}$ ): $\delta$ 1.91-2.03 (m, 2H, CHOHCH $) ; 2.38-2.51\left(\mathrm{~m}, 6 \mathrm{H}, \mathrm{CHCH}_{2} \mathrm{CH}_{2}+2 \mathbf{H}_{2}+\right.$ $\mathbf{2 H}_{6}$ piperazine); 2.96 (bs, $4 \mathrm{H}, \mathbf{2 H}_{3}+\mathbf{2 H}_{\mathbf{5}}$ piperazine); 3.76 (s, $\left.3 \mathrm{H}, \mathrm{OCH}_{3}\right) ; 4.92$ (t, $\left.1 \mathrm{H}, \mathrm{CHOH}\right) ; 5.16$ (bs, 1H, OH); 6.87-6.98 (m, 5H, $\mathbf{H}_{3},+\mathbf{H}_{4},+\mathbf{H}_{5},+\mathbf{H}_{6}$, phenyl $+\mathbf{H}_{6}$ indolyl); 7.04-7.06 (t, 1H, $\mathbf{H}_{5}$ indolyl, $\left.J_{5,6}=8.0 \mathrm{~Hz}, J_{5,4}=7.4 \mathrm{~Hz}\right) ; 7.20\left(\mathrm{~s}, 1 \mathrm{H}, \mathbf{H}_{2}\right.$ indolyl); $7.33\left(\mathrm{~d}, 1 \mathrm{H}, \mathbf{H}_{7}\right.$ indolyl, $\left.\mathrm{J}_{7,6}=8.4 \mathrm{~Hz}\right) ; 7.63(\mathrm{~d}$, $1 \mathrm{H}, \mathbf{H}_{4}$ indolyl, $\left.\mathrm{J}_{4,5}=7.4 \mathrm{~Hz}\right) ; 10.83(\mathrm{~s}, 1 \mathrm{H}, \mathrm{NH}) \mathrm{ppm}$; Anal. Calcd. for $\left(\mathrm{C}_{22} \mathrm{H}_{27} \mathrm{~N}_{3} \mathrm{O}_{2}\right) \mathrm{C}, 72.33 ; \mathrm{H}$, 7.39; N, 11.51. Found: C, 72.23; H, 7.85; N, 11.19 .

Dihydrochloride of 1-(6-methylnapth-2-yl)-3-[4-(2-methoxyphenyl) piperazin-1-yl]propan-1-ol (44). Yield 35\%; M.p.: $116-117{ }^{\circ} \mathrm{C}$; ${ }^{1} \mathrm{H}-\mathrm{NMR}$ (DMSO-d $\left.{ }_{6}\right): \delta 2.10-2.19\left(\mathrm{~m}, 2 \mathrm{H}, \mathrm{CHCH}_{2}\right) ; 2.47\left(\mathrm{~s}, 3 \mathrm{H}, \mathrm{CH}_{3}\right)$; 2.95-3.02 (m, 2H, $\mathbf{H}_{2 \mathbf{a x}}+\mathbf{H}_{6 \mathbf{6 x}}$ piperazine); 3.16-3.29 (m, 4H, $\mathbf{H}_{2 \mathbf{e c}}+\mathbf{H}_{6 \mathbf{6 e c}}$ piperazine $+\mathrm{CHCH}_{2} \mathrm{CH}_{2}$ ); 3.45-3.57 (m, $4 \mathrm{H}, \mathbf{H}_{3}+\mathbf{H}_{5}$ piperazine); $3.78\left(\mathrm{~s}, 3 \mathrm{H}, \mathrm{OCH}_{3}\right) ; 4.80-4.83(\mathrm{~m}, 1 \mathrm{H}, \mathrm{CH}) ; 6.91-7.05(\mathrm{~m}, 4 \mathrm{H}$, $\mathbf{H}_{3}, \mathbf{H}_{4}, \mathbf{H}_{5}, \mathbf{H}_{\mathbf{6}}$, phenyl); $7.36\left(\mathrm{~d}, 1 \mathrm{H}, \mathbf{H}_{7}\right.$ naphthyl, $\left.J_{7,8}=8.4 \mathrm{~Hz}\right) ; 7.50\left(\mathrm{~d}, 1 \mathrm{H}, \mathbf{H}_{3}\right.$ naphthyl, $J_{3,4}=8.8$ $\mathrm{Hz}$ ); 7.67 (s, $1 \mathrm{H}, \mathbf{H}_{5}$ naphthyl); 7.81 (m, 3H, $\mathbf{H}_{\mathbf{1}}+\mathbf{H}_{\mathbf{4}}+\mathbf{H}_{\mathbf{8}}$ naphthyl) ppm; Anal. Calcd. for $\left(\mathrm{C}_{25} \mathrm{H}_{30} \mathrm{~N}_{2} \mathrm{O}_{2}\right.$. 2HCl) C, 64.79; H, 6.91; N, 6.04. Found: C, 64.62; H, 7.05; N, 5.88.

Hydrochloride of 1-(2-naphthyl)-3-[3-(4-nitro-2-trifluoromethylphenyl)-(S)-pyrrolidin-3-yl amino]propan-1-ol (45). Yield 20\%; Mp.: 181-183 ${ }^{\circ} \mathrm{C} ;{ }^{1} \mathrm{H}-\mathrm{NMR}$ (DMSO-d $_{\text {) }} \delta$ 2.07-2.14 (m, 2H, CHOH$\mathrm{CH}_{2}$ ); 2.29-2.31 (m, 1H, $\mathbf{H}_{4 \text { ec }}$ pyrrolidine); 2.36-2.41 (m, 1H, $\mathbf{H}_{4 \mathbf{a x}}$ pyrrolidine); 3.11 (bs, 2H, CHOH$\mathrm{CH}_{2}-\mathrm{CH}_{2}$ ); 3.57-3.64 (m, 1H, $\mathbf{H}_{2 \mathbf{2 e c}}$ pyrrolidine); 3.75-3.79 (m, 2H, $\mathbf{H}_{5 \mathbf{e c}}+\mathbf{H}_{2 \mathbf{a x}}$ pyrrolidine); 3.85-3.89 (m, 1H, $\mathbf{H}_{5 \mathbf{a x}}$ pyrrolidine); 3.97 (bs, 1H, $\mathbf{H}_{3}$ pyrrolidine); 5.90 (bs, 1H, CHOH); 5.76 (s, 1H, OH); 7.10 (d, $1 \mathrm{H}, \mathbf{H}_{6}$, phenyl, $\left.J_{6^{\prime}, 5}{ }^{\prime}=9.6\right) ; 7.47-7.55\left(\mathrm{~m}, 3 \mathrm{H}, \mathbf{H}_{3}+\mathbf{H}_{\mathbf{6}}+\mathbf{H}_{7}\right.$ naphthyl); 7.86 (s, 1H, $\mathbf{H}_{\mathbf{1}}$ naphthyl); 7.90-7.92 (m, 3H, $\mathbf{H}_{\mathbf{4}}+\mathbf{H}_{5}+\mathbf{H}_{\mathbf{8}}$ naphthyl); 8.24-8.9 (d, $1 \mathrm{H}, \mathbf{H}_{5}$, phenyl, $J_{5}, 6^{\prime}=9.5$ ); 8.40 (s, $1 \mathrm{H}, \mathbf{H}_{3}$, phenyl); 9.49 (bs, $1 \mathrm{H}, \mathrm{NH})$ ppm; Anal. Calcd. for $\left(\mathrm{C}_{24} \mathrm{H}_{24} \mathrm{~N}_{3} \mathrm{~F}_{3} \mathrm{O}_{3} . \mathrm{HCl}\right) \mathrm{C}, 58.24 ; \mathrm{H}, 5.04 ; \mathrm{N}, 8.48$. Found: C, 57.87; H, 4.92; N, 8.21.

\section{Conclusions}

The biological evaluation showed a broad range of activities, thereby offering new structural hits for future chemical pharmacomodulation of 1-aryl-3-substituted propanol derivatives as a new therapeutic option for the treatment of malaria.

\section{Acknowledgements}

This work has been carried out with the financial support of the PIUNA Project from University of Navarra. A. M. is indebted to the Navarra Government for a grant. 


\section{References and Notes}

1. Snow, R.W.; Guerra, C.A.; Noor, A.M.; Myint, H.Y.; Hay, S.I. The global distribution of clinical episodes of Plasmodium falciparum malaria. Nature 2005, 434, 214-217.

2. White, N.J. Antimalarial drug resistance. J. Clin. Inv. 2004, 113, 1084-1092.

3. Tran, T.M.; Browning, J.; Dell, M.L. Psychosis with paranoid delusions after a therapeutic dose of mefloquine: A case report. Malar. J. 2006, 5, 74.

4. Taylor, W.R.J.; White N.J. Antimalarial drug toxicity: A review. Drug Safety 2004, 27, $25-61$.

5. WHO. Strategic and technical meeting on intensified control of neglected tropical diseases. A renewed effort to combat entrenched communicable diseases of the poor. Guidelines for the treatment of malaria. World Health Organization: Geneva, Switzerland, 2006. http://www.popline.org/docs/312474, accessed on 10 October 2009.

6. Clarkson, C.; Musondab, C.C.; Chibaleb, K.; Campbella, W.E.; Smith, P. Synthesis of totarol amino alcohol derivatives and their antiplasmodial activity and cytotoxicity. Bioorg. Med. Chem. 2003, 11, 4417-4422.

7. Robin, A.; Brown, F.; Bahamontes-Rosa, N.; Wu, B.; Beitz, E.; Kun, J.; Flitsch, S.L. Microwaveassisted ring opening of epoxides: A general route to the synthesis of 1-aminopropan-2-ols with anti malaria parasite activities. J. Med. Chem. 2007, 50, 4243-4249.

8. D'hooghe, M.; Dekeukeleire, S.; Mollet, K.; Lategan, C.; Smith, P.J.; Chibale, K.; De Kimpe, N. Synthesis of Novel 2-alkoxy-3-amino-3-arylpropan-1-ols and 5-alkoxy-4-aryl-1,3-oxazinanes with antimalarial activity. J. Med. Chem. 2009, 52, 4058-4062.

9. Orus, L.; Pérez-Silanes, S.; Oficialdegui, A.; Martinez, J.; Del Castillo, J.C.; Mourelle, M.; Langer, T.; Guccione, S.; Donzella, G.; Krovat, E.M.; Poptodorov, K.; Lasheras, B.; Ballaz, S.; Hervías, I.; Tordera, R.; Del Río, J.; Monge, A.M. Synthesis and molecular modeling of new 1aryl-3-[4-arylpiperazin-1-yl]-1-propane derivatives with high affinity at the serotonin transporter and at 5-HT1A receptors. J. Med. Chem. 2002, 45, 4128-4139.

10. Martínez-Esparza, J.; Oficialdegui, A.M.; Pérez-Silanes, S.; Heras, B.; Orús, L.; Palop, J.A.; Lasheras, B.; Roca, J.; Mourelle, M.; Bosch, A.; Del Castillo, J.C.; Tordera, R.; Del Río, J.; Monge, A. New 1-(aryl)-3-[4-(aryl)piperazin-1-yl]-propane derivatives with dual action at 5HT1A serotonin receptors and serotonin transporter as a new class of antidepressants. J. Med. Chem. 2001, 44, 418-428.

11. Martínez, J.; Pérez, S.; Oficialdegui, A.M.; Heras, B.; Orús, L.; Villanueva, H.; Palop, J.A.; Roca, J.; Mourelle, M.; Bosch, A.; Del Castillo, J.C.; Lasheras, B.; Tordera, R.; Del Río, J.; Monge, A. New 3-[4-(aryl)piperazin-1-yl]1-(benzo[b]thiophen-3-yl)propane derivatives with dual action at 5-HT1A serotonin receptors and serotonin transporter as a new class of antidepressants. Eur. J. Med. Chem. 2001, 36, 55-61.

12. Oficialdegui, A.; Martínez-Esparza, J.; Pérez-Silanes, S.; Heras, B.; Irurzun, M.; Palop, J.A.; Monge; A. Design, synthesis and biological evaluation of new 3-[(4-aryl)piperazin-1-yl]-1-aryl propane derivatives as potential antidepressants with a dual mode of action: serotonin reuptake inhibition and 5-HT1A receptor antagonism. Farmaco 2000, 55, 345-353.

13. Bruckner, R. Advanced Organic Chemistry: Reaction Mechanisms; Harcourt/Academic Press: San Diego, CA, USA, 2002. 
14. Dorn, A.; Vippagunta, S.R.; Matile, H.; Bubendorf, A.; Vennerstrom, J.L.; Ridley, R.G. A comparison and analysis of several ways to promote haematin (Haem) polymerisation and an assessment of its initiation in vitro. Biochem. Pharmacol. 1998, 55, 737-747.

15. Deharo, E.; García, R.N.; Oporto, P.; Gimenez, A.; Sauvain, M.; Jullian, V.; Ginsburg, H. A nonradiolabeled ferriprotoporphyrin IX biomineralization inhibition test (FBIT) for the high throughput screening of ant malarial compounds. Exp. Parasitol. 2002, 100, 252-256.

16. Smilkstein, M.; Sriwilaijaroen, N.; Xu, J.; Prapon, K.; Riscoe, M. Simple and inexpensive fluorescence-based technique for high-throughput antimalarial drug screening. Antimicrob. Agents Chemother. 2004, 48, 1803-1807.

17. Hattori, Y.; Nakanishi, N. Effects of Cyclosporin A and FK506 on nitric oxide and tetrahydrobiopterin synthesis in bacterial lipopolysacharide- treated J774 macrophages. Cell. Inmunol. 1995, 165, 7-11.

18. Peters, W. Chemotherapy and Drug Resistance in Malaria; Academic Press: New York, NY, USA, 1970.

Sample Availability: Contact the authors.

(C) 2009 by the authors; licensee Molecular Diversity Preservation International, Basel, Switzerland. This article is an open-access article distributed under the terms and conditions of the Creative Commons Attribution license (http://creativecommons.org/licenses/by/3.0/). 